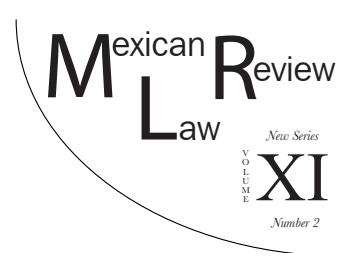

\title{
THE RIGHT TO A GLEAN AND HEALTHY ENVIRONMENT: GMOS IN MEXICO AND THE EUROPEAN UNION
}

\author{
Alicia Gutiérrez GonZÁLeZ*
}

\begin{abstract}
The main objective of this article is to give an overview of both the right to a clean and healthy environment adopted in international and national agreements, and the effects that the release of genetically modified organisms $(G M O s)$ into the environment (especially genetically modified maize) may cause to human, animal and plant health. This article is divided into three sections: The first section focuses on the right to a clean and healthy environment and its enjoyment as a third generation human right in Mexico and the European Union; the second section briefly examines the global status of commercialized biotech/GM crops worldwide as well as the benefits and risks that the release of GMOs into the environment may cause to human, animal and plant health, and looks at the lack of protection of maize in Mexico as a Centre of Origin and Centre of Genetic Diversity (COD); and the third section analyses and compares the insufficient legal protection in Mexico with the strict legal regime in the European Union regarding the release of GMOs into the environment. I propose that Mexico should only cultivate genetically modified maize using biosafety techniques in arid zones, with the aim of protecting the genetic diversity of maize. This contrasts with the EU regulations because the EU has no genetic diversity of maize to protect. In increasing protections and following specific programs for the cultivation of genetically modified maize, the right to a clean and healthy environment could be guaranteed.
\end{abstract}

Keywords: Climate Change, Environment, GMOs, Maize, Third Generation Human Rights.

RESUMEN: El objetivo de este artículo es dar una visión general del derecho a un medio ambiente sano consagrado en instrumentos nacionales e internacio-

* Faculty of Law, Anahuac University, Mexico. Professor at the Law Faculty of the Tec de Monterrey, Campus Ciudad de México, and at the International Relations Faculty of ITAM, Campus Rio Hondo. Law studies and a Master Degree in coorporative law at the University of Guadalajara, México. Master and Doctor degree at the Georg-August-University-Göttingen. Member of the National System of Researchers, (SNI), Level I, Mexico. Email: aliciagtzglez@gmail.com. 
Esta revista forma parte del acervo de la Biblioteca Jurídica Virtual del Instituto de Investigaciones Jurídicas de la UNAM http://www.juridicas.unam.mx/ https://biblio.juridicas.unam.mx/bjv https://revistas.juridicas.unam.mx/ http://dx.doi.org/10.22201/iij.24485306e.2019.1.13129

nales que toman en consideración los principios ambientales, y los efectos que la liberación de los organismos genéticamente modificados (OGMs) en el medio ambiente (especialmente el GM-Maíz) pueden causar a la salud humana, animal y vegetal. Este artículo se divide en tres partes: la primera parte trata sobre el derecho a disfrutar de un medio ambiente sano como derecho humano de tercera generación en México y en la Unión Europea. La segunda parte muestra brevemente el estatus global de los OGMs a nivel mundial, así como los beneficios y riesgos que la liberación de OGMs en el medio ambiente pueden causar a la salud humana, animal y vegetal. También menciona la falta de protección del maíz en un Centro de Origen y de Diversificación Genética (COD). La tercera parte analiza y compara el insuficiente regimen de protección legal en México con el estricto regimen legal de la Unión Europea (UE) en lo que respecta a la liberación de OGMs en el medio ambiente. También explica que México debe cultivar solamente GM-Maiz en zonas aridas y siempre y cuando se hayan implementado medidas de seguridad. Esto con el objetivo de proteger la diversidad genética del maíz. Esta última contrasta con las regulaciones de la UE porque ahi no hay diversidad genetica del maiz que proteger. Al hacerlo, el derecho a un medio ambiente sano podría ser garantizado.

Palabras clave: Cambio climático, medio ambiente, OGMs, maíz, tercera generación de derechos humanos.

\section{TABLE OF CONTENTS}

I. The Right to a Cleman and Healthy Environment ……………..... 93

1. Third Generation Human Rights ............................................... 93

2. The Right to a Clean and Healthy Environment and its Enjoyment as a Human Right

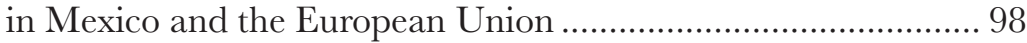

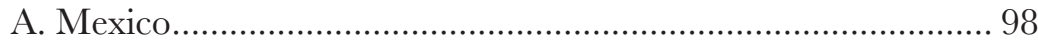

B. The European Union ................................................................ 99

II. GMOs and their Impact on Human, Animal and Plant Health .....

1. Global Status of Commercialized Biotech/GM

Crops Worldwide

2. Benefits and Risks of the Release of GMOs

Into the Environment and its Effects on Human,

Animal and Plant Health.

III. The Legal Framework for the Release of Genetically

Modified Maize Into the Environment in Mexico

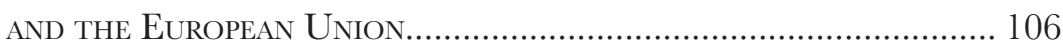

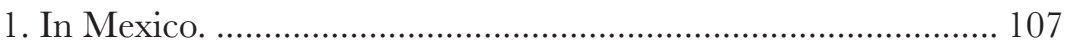

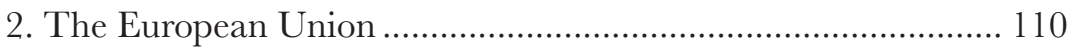

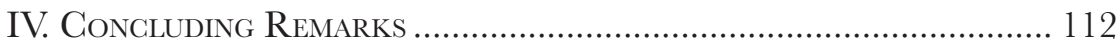




\section{The Right to a Clean and Healthy Environment}

\section{Third Generation Human Rights}

Academic literature on the Rights of peoples generally refers to: (i) the right to food, (ii) the right to a decent environment, (iii) the right to development and, (iv) the right to peace. ${ }^{1}$ In addition, César Nava Escudero writes that "The doctrine and the domestic law of many countries have included also the right to self-determination into the solidarity rights or into third generation human rights. ${ }^{\prime 2}$ First generation human rights are set out in the International Covenant on Civil and Political Rights (ICCPR), and second generation human rights are outlined in the International Covenant on Economic, Social and Cultural Rights (ICESCR).

The laws for the protection of the environment have increasingly been influenced by, and been seen in the perspective of, laws relating to development and human rights. ${ }^{3}$ Thus, the majority of the international community considers that the right to a clean and healthy environment be included as a collective/solidarity right or integrated into third generation rights. Patricia Birnie, Alan Boyle and Catherine Redgwell explain that today there exists an international human right to a clean environment. ${ }^{4}$ Nevertheless, Birnie et al. mention that not all human rights lawyers favour the recognition of third generation rights, arguing that this devalues the concept of human rights, and diverts attention from the need to fully implement existing civil, political, economic and social rights. In addition, the authors claim that environmental rights do not fit neatly into any single category or generation of human rights and therefore can be viewed from three perspectives:

(i) Existing civil and political rights can provide a basis for giving affected individuals access to environmental information, judicial remedies, and political processes.

(ii) The environment should be treated as an economic social or cultural right.

(iii) The environmental quality would be treated as a collective or solidarity right. ${ }^{5}$

\footnotetext{
1 Ian Brownlie, Principles of Public International LaW 567, (New York, Oxford University Press) (2008).

2 César Nava Escudero, Derecho al medio ambiente, in Diccionario de DERECho PROCESAL CONSTITUCiONAL y CONVEncional 399, (Instituto de Investigaciones Jurídicas, UNAM) (2014).

3 Antonio Cassese, International Law 488, (New York, Oxford University Press) (2005).

4 Patricia Birnie Et Al., International LaW \& The Environment, (New York, Oxford University Press) (2009).

5 Patricia Birnie et al., supra note 4, at 271-272.
} 
David Boyd writes: "The suggestion that there are three generations of rights is controversial, and no global Human Rights treaty recognizes thirdgeneration rights in the same way that the two International Covenants enshrine civil, political, economic, social and cultural rights. ${ }^{\prime 6}$ It follows that the evolution and development of international environmental principles had an important impact after 1970. There are two international treaties, which have been adopted some environmental principles enshrining environmental law worldwide: (i) the 1972 Declaration of the United Nations Conference on the Human Environment (Stockholm Declaration), ${ }^{7}$ and (ii) the 1992 Rio Declaration on Environment and Development (Rio Declaration). ${ }^{8}$

On the one hand, the Stockholm Declaration states that:

(i) Man has the fundamental right to freedom, equality and adequate conditions of life, in an environment of a quality that permits a life of dignity and well-being, and he bears a solemn responsibility to protect and improve the environment for present and future generations.

(ii) The natural resources of the earth must be safeguarded for the benefit of present and future generations.

(iii) States have the responsibility to ensure that activities within their jurisdiction or control do not cause damage to the environment of other States or of areas beyond the limits of national jurisdiction and

(iv) International cooperation is essential to effectively control, prevent, reduce and eliminate adverse environmental effects.

\section{On the other hand, the Rio Declaration establishes that:}

(i) Human beings are at the centre of concerns for sustainable development.

(ii) The international cooperation is crucial to conserve, protect, and restore the health and integrity of the Earth's ecosystem.

(iii) States have common but differentiated responsibilities.

6 David Boyd, R., The Environmental Rights Revolution: A Global, Human Rights, AND the Environment 22 (UBC Press, Canadá) (2012).

7 Declaration of the United Nations Conference on the Human Environment, Stockholm Declaration. On June 5-16, 1972, delegations from 114 countries met for the UN Conference on the Human Environment, widely regarded as the first global environmental conference. The Conference produced many documents, including this Declaration which contains 26 principles, several of which have been incorporated into subsequent international environmental agreements. U.N. Doc. A/Conf.48/14/Rev. 1(1973); 11 ILM 1416 (1972). http://werere. unep.org $/$ Documents $/$ Default.asp?DocumentID $=97$ \&ArticleID $=1503$.

8 The Rio Declaration on Environment and Development is one of five agreements coming out of the United Nations Conference on Environment and Development (also called the "Earth Summit") in Rio de Janeiro in June 1992. Although a non-binding, or "soft law" instrument, the Rio Declaration sets forth important principles of international environmental law, especially sustainable development. UN Doc. A/CONF.151/26 (vol. I); 31 ILM 874 (1992). http: / / wrerce.unep.org $/$ Documents $/$ Default.asp?'DocumentID $=78$ \&ArticleID $=1163$. 
(iv) The precautionary approach shall be widely applied by States according to their capabilities.

(v) The approach that the polluter should, in principle, bear the cost of pollution, with due regard to the public interest and without distorting international trade and investment, and

(vi) States shall immediately notify other States of any natural disasters or other emergencies that are likely to produce sudden harmful effects on the environment of those States.

The most important principles ruling international environmental law arising from these two declarations include:

(i) The polluter pays principle.

(ii) The precautionary principle.

(iii) The principle of sustainable development.

(iv) The principle of common but differentiated responsibilities.

(v) The principle of State sovereignty over their natural resources and the responsibility not to cause transboundary environmental damage.

(vi) The principle of international cooperation and,

(vii) The principle of preventive action as well.

The precautionary principle, the preventive action principle and the principle of international cooperation are the foundation of the environmental principles. ${ }^{9}$ It is important to mention that human rights considerations, nor the right to a clean and healthy environment were addressed in the context of development before the 1990's, ${ }^{10}$ rather, this is a trend that began after the end of Cold War. Antonio Cassese explains that "the environment has come to be regarded as a common amenity, as an asset in the safeguarding of which all should be interested, regardless of where the environment is or may be harmed."11

Needless to say, the 1997 Kyoto Protocol ${ }^{12}$ and the 2015 Paris Agreement ${ }^{13}$ are of crucial importance to understand the right to a clean and healthy en-

9 Reiner Schmidt, EimfüHrung IN DAS UmWeLtrecht 4, 6. Ed., München, C.H. Beck (2001).

10 Philip Alston et al., International Human Rights, the Succesor to International Human RightS IN CONTEXT 1517, (UK, Oxford University Press) (2013).

11 Antonio Cassese, supra note 3, at 487.

12 Kyoto Protocol to the United Nations Framework Convention on Climate Change. In 1997160 nations met in Kyoto to negotiate reductions in greenhouse gas emissions pursuant to the terms of the 1992 United Nations Framework Convention on Climate Change. The resulting agreement is this document, which sets forth specific limits on emissions. UN Doc FCCG/CP/1997/7/Add.1, Dec. 10, 1997; 37 ILM 22 (1998) http://unfccc.int/essential_background/kyoto_protocol/background/items/1351.php.

13 The Paris Agreement's central aim is to strengthen the global response to the threat of climate change by keeping a global temperature rise this century well below 2 degrees Celsius above pre-industrial levels and to pursue efforts to limit the temperature increase even further 
Esta revista forma parte del acervo de la Biblioteca Jurídica Virtual del Instituto de Investigaciones Jurídicas de la UNAM http://www.juridicas.unam.mx/ https://biblio.juridicas.unam.mx/bjv https://revistas.juridicas.unam.mx/ http://dx.doi.org/10.22201/iij.24485306e.2019.1.13129

vironment, because they regulate international level the emissions of Greenhouse Gases, (GHGs), which make up part of the impacts on human, plant and animal health. The seven main GHGs are:
(i) Carbon Dioxide (CO2)
(ii) Methane $(\mathrm{CH} 4)$
(iii) Nitrous Oxide (N20)
(iv) Hydrofluorocarbons (HFCs)
(v) Perfluorocarbons (PFGs)
(vi) Sulphur Hexafluoride (SF6) and
(vii) Nitrogen Triflouride (NF3)

The essence of the Kyoto Protocol seeks to cut back the emissions of industrial and transition economies so that their emissions fall to five per cent below 1990 levels, and to freeze them at that level, while allowing developing countries the right to emit unlimited emissions. ${ }^{14}$ This was designed to assist countries in adapting to the adverse effects of climate change and to guarantee the right to a clean and healthy environment. The Kyoto Protocol places a heavier burden on developed countries under the principle of common but differentiated responsibilities because they are mainly responsible for the high levels of GHG emissions in the atmosphere as a result of more than 150 years of industrial activity. ${ }^{15}$ Its first commitment period started in 2008 and ended in 2012. During this second period from 2013 to 2020, Parties committed to reduce GHG emissions by at least 18 per cent below 1990 levels over the eight-year period. For instance, the EU's internal 20 per cent target is also the basis for its international commitments under the Kyoto Protocol's second comminment period. ${ }^{16}$ "The Kyoto Procol is seen as an important first step towards a truly global emission reduction regime that will stabilize GHG emissions." 17

\footnotetext{
to 1.5 degrees Celsius. Additionally, the agreement aims to strengthen the ability of countries to deal with the impacts of climate change. To reach these ambitious goals, appropriate financial flows, a new technology framework and an enhanced capacity building framework will be put in place, thus supporting action by developing countries and the most vulnerable countries, in line with their own national objectives. The Agreement also provides for enhanced transparency of action and support through a more robust transparency framework. http://unfcccint/ paris_agreement/items/9485.php.

14 Bjorn Lomborg, Global Crises, Global Solutions 28, (UK, Cambridge University Press) (2004).

15 The kyoto Protocol was adopted in Kyoto, Japan, on 11 December 1997 and entered into force on 16 February 2005. The rules for the implementation were adopted at COP 7 in Marrakesch, Morocco, in 2001. For more information see the Conference of the Parties (COP) such as: (i) 2001 COP 7, (ii) 2006 COP 12 and, (iii) 2010 COP 16.

16 See: http://ec.europa.eu/eurostat/statistics-explained/index.php/Greenhouse_gas_emission_statistics.

17 For more information see: http://unfccc.int/kyoto_protocol/items/2830.php.
} 
The Paris Agreement was adopted on 12 December at the twenty-first session of the Conference of the Parties to the United Nations Framework Convention on Climate Change (COP 21), and entered into force on 4 November 2016. It states in Preamble 11 that "Climate change is a common concern of humankind, therefore, the international community should, when taking action to address climate change, respect, promote and consider their respective obligations on human rights, the right to health, the rights to indigenous peoples, local communities, the right to development, as well as gender equality, empowerment of women and intergenerational equity." ${ }^{\prime 18}$ To date, of 197 Parties to the Convention, 168 have ratified. ${ }^{19}$

In this context, the United Nations Framework Convention on Climate Change (UNFCCG) $)^{20}$ states "the long-term objective is to stabilise atmospheric GHG concentrations at a level that would prevent dangerous anthropogenic interference with the climate system." In order to reduce GHGs, the international community must adopt and implement at national, regional and local levels the approaches adaptation and mitigation. The Intergovernmental Panel on Climate Change (IPPC) defines adaptation as "adjustment in natural or human system in response to actual or expected climatic stimuli or their effects, which moderates harm or exploits beneficial opportunities." ${ }^{21}$ In addition, it defines mitigation as "an anthropogenic intervention to reduce anthropogenic forcing of the climate system. It includes strategies to reduce greenhouse gas sources and emissions and enhancing greenhouse gas sinks." ${ }^{22}$ Thus, one of the main goals of the Paris Agreement is the implementation of the approaches explained above in order to reduce GHGs and to protect the environment, human, plant and animal health, as well as the planet earth.

As aforementioned, the right to a clean and healthy environment is considered a third generation human right, and therefore must be seen as other human rights, because human rights are universal, indivisible, interdependent and interrelated. As the environment can be considered as a common

18 Paris Agreement, Article 20 states this Agreement shall be open for signature at the United Nation Headquarters in New York from 22 April 2016 to 21 April 2017. Article 21 states that this Agreement shall enter into force on the thirtieth day after the date on which at least 55 Parties to the Convention accounting in total for at least an estimated 55 per cent of the total global greenhouse gas emissions have deposited their instruments of ratification, acceptance, approval or accession.

19 Paris Agreement - Status of ratification, United Nations Framework Convention on Climate Change, http://unfccc.int/paris_agreement/items/9444.php.

20 For more information see: The United Nations Framework Convention on Climate Change (UNFCCG) http://unfccc.int/essential_background/convention/items/6036.php.

21 Intergovernmental Panel on Climate change (IPCG) Fourth Assessment Report: Climate Change 2007, Working Group II: Impacts, Adaptation and Vulnerability. Appendix I. Glossary A-D https://wrwreipcc.ch/publications_and_data/ar4/wg2/en/annexessglossary-a-d.html.

22 Ibid, Appendix I. Glossary E-O. 
Esta revista forma parte del acervo de la Biblioteca Jurídica Virtual del Instituto de Investigaciones Jurídicas de la UNAM http://www.juridicas.unam.mx/ https://biblio.juridicas.unam.mx/bjv https://revistas.juridicas.unam.mx/ http://dx.doi.org/10.22201/iij.24485306e.2019.1.13129

amenity, it must be protected so that human beings can enjoy a safe, clean, healthy and sustainable environment. Environmental damage has negative implications on human health, directly and indirectly. Thus, for the effective enjoyment of such human rights, including the right to life, the right to the enjoyment of the highest attainable standard of physical and mental health, the right to an adequate standard of living and its components, (such as the right to food, and the rights to safe drinking water and sanitation, and to adequate housing), the right to a clean and healthy environment must be protected at local, regional and international levels. ${ }^{23}$

\section{The Right to a Clean and Healthy Environment and its Enjoyment as a Human Right in Mexico and the European Union}

\section{A. Mexico}

Mexico is a member state of the Organization of American States (OAS $)^{24}$ and the European Union is a permanent observer of this Organization. The right to live in a healthy environment is included into the Additional Protocol to the American Convention on Human Rights in the Area of Economic, Social and Cultural Rights, known as the "Protocol of San Salvador" ${ }^{25}$ of which Article 11 states:

\section{Right to a Healthy Environment}

1. Everyone shall have the right to live in a healthy environment and to have access to basic public services.

2. The States Parties shall promote the protection, preservation, and improvement of the environment.

This protocol was signed by Mexico and therefore has a regional obligation to protect the environment, as do other member states, including: Antigua Barbuda; Argentina; Bahamas; Barbados; Belize; Bolivia; Brazil; Canada; Chile; Colombia; Costa Rica; Dominica; Dominican Republic; Ecuador; El Salvador; Grenada; Guatemala; Guyana; Haiti; Honduras; Jamaica; Mexico;

23 Human Rights Council, twenty-fifth session, agenda item 3, promotion and protection of all human rights, civil, political, economic, social and cultural rights, including the right to development, on 24 of march, 2014 of the United Nations A/HRC/25/L.31.

24 The Organization of American States, wrew.oas.org/es/sla/ddi/tratados_multilaterales_interamericanos_A-41_carta_OEA_firmas.asp.

25 The Additional Protocol to the American Convention on Human Rights in the Area of Economic, Social and Cultural Rights "Protocol of San Salvador", (17.11.1988), http://wrww. oas.org/juridico/english/treaties/a-52.html. 
Nicaragua; Panama; Paraguay; Peru; St. Kitts \& Nevis; St. Lucia; St. Vincent \& Grenadines; Suriname; Trinida \& Tobago; United States; Uruguay; Venezuela.

Mexico has had environmental provisions in its national constitution since 1971, according to Article 73, XVI, 4, which states that: "The Congress has the power to adopt measures to prevent and combat environmental pollution." ${ }^{26}$ The right to live in an environment that is adequate for human development and well-being was adopted in 1999, under Article $4 .^{27}$ Since 2012, the right to a clean and healthy environment and its enjoyment as a human right is founded in the Political Constitution of the United Mexican States under Article 4 paragraph 5. This Article was amended with the aim to guarantee the right to a healthy environment and states: "Any person has the right to a healthy environment for his/her own development and wellbeing. The State shall guarantee the respect to such right. Environmental damage and deterioration will generate a liability for whoever provokes them in terms of the provisions by the law." 28

It is worth mentioning that Article 1 of the Mexican Constitution was amended in 2011 with the aim of enabling the enforcement of the right to healthy environment, among other human rights. ${ }^{29}$ Thus, the Mexican state guarantees its citizens the right to a clean and healthy environment and its enjoyment as a third generation human right. This is granted by the Mexican Constitution and by all international instruments to this matter signed by the Mexican state.

\section{B. The European Union}

On the other hand, the European Union has some of the world's highest environmental regulations, developed since the 1970s. The EU does not guarantee explicitly the right to a clean and healthy environment and its enjoyment as a third generation human right but 16 of its member states have

${ }^{26}$ Constitución Política de los Estados Unidos Mexicanos [Const.], as amended, Diario Oficial de la Federación [D. O], 5 de febrero de 1917 (Méx.).

27 Ibid, Article 4, http://werere.diputados.gob.mx/LeyesBiblio/ref/dof/CPEUM_ref_141_28jun99_ ima.pdf.

28 Ibid, Article 4 paragraph 5, amended through decree published on February 8th, 2012. http://wrerrediputados.gob.mx/LeyesBiblio/ref/dof/CPEUM_ref_200_08feb12.pdf.

29 Ibid, Article 1. The first paragraph was reformed by decree published on June 10, 2011. The first paragraph states that: "In the United Mexican States, all individuals shall be entitled to the human rights granted by this Constitution and the international treaties signed by the Mexican State, as well as to the guarantees for the protection of these rights. Such human rights shall not be restricted or suspended, except for the case and under the conditions established by this Constitution itself". 
adopted this right into its national constitutions, ${ }^{30}$ these are: Portugal (1976); Spain (1978); Netherlands (1983); Hungary (1989); Croatia (1990); Bulgaria and Slovenia (1991); Czech Republic and Slovakia (1992); Belgium (1994); Finland (1995); Poland (1997); Latvia (1998); Greece (2002); Romania (2003) and France (2005). ${ }^{31}$ In addition, 23 member states have environmental provisions in their national constitutions, these are: Italy (1948); Malta (1964); Greece (1975); Portugal (1976); Spain (1978); Netherlands (1983); Austria (1984); Sweden (1987); Hungary (1989); Croatia (1990); Bulgaria and Slovenia (1991); Czech Republic, Estonia, Lithuania, (1992); Belgium and Germany (1994); Finland (1995); Poland (1997); Latvia (1998); Romania (2003); France (2005) and Luxembourg (2007). ${ }^{32}$

The EU ratified the Aarhus Convention on Access to Information, Public Participation in Decision-making and Access to Justice in Environment Matters on February 17, 2005. ${ }^{33}$ The objective of this Convention is stated in Article 1 as follow: "In order to contribute to the protection of the right of every person of present and future generations to live in an environment adequate to his or her health and well-being, each Party shall guarantee the rights of access to information, public participation in decision-making, and access to justice in environmental matters in accordance with the provisions of this convention". The EU environment policy is founded on Articles 11 and 191-193 of the Treaty on the Functioning of the European Union. ${ }^{34}$

Article 191 states:

1. "Union policy on the environment shall contribute to pursuit of the following objectives:

- Preserving, protecting and improving the quality of the environment,

- Protecting human health,

- Prudent and rational utilisation of natural resources,

- Promoting measures at international level to deal with regional or worldwide environmental problems, and in particular combating climate change".

2. "Union policy on the environment shall aim at a high level of protection taking into account the diversity of situations in the various regions of the Union. It shall be based on the precautionary principle and on the principles

30 The European Union has a share competence with the Member States, according to Article four of the Treaty of Functioning of the European Union. The matters that are relevant include: (i) agriculture; (ii) environment; (iii) consumer protection; and common safety concerns in public health matters.

31 David Boyd R., supra note 6, at 63.

32 Ibid, at. 50.

33 The Convention on Acces to Information, Public Participation in Decision-Making and Acces to Justice in Environmental Matters, (Aarhus, Denmark, 25 June 1988). It entered into force on 30 October 2001, in accordance with article 20(1). https://treaties.un.org/Pages/ ViewDetails.aspx?src $=I N D$ Emtdsg_no $=X X V I I-13$ Echapter $=27$ Eclang $=\_$en .

34 Consolidated version of the Treaty on the Functioning of the European Union. C 326/132 EN Official Journal of the European Union, 26.10.2012. 
that preventive action should be taken, that environmental damage should as a priority be rectified at source and that the polluter should pay."

In this context, harmonisation measures answering environmental protection requirements shall include, where appropriate, a safeguard clause allowing Member States to take provisional measures, for non-economic environmental reasons, subject to a procedure of inspection by the Union.

3. In preparing its policy on the environment, the Union shall take account of: - available scientific and technical data, - environmental conditions in the various regions of the Union, - the potential benefits and costs of action or lack of action, - the economic and social development of the Union as a whole and the balanced development of its regions.

Combating climate change is an explicit objetive of this Article. Article 3 of the Treaty on European Union invokes the sustainable development for the protection of a high level of protection and the improvement of the quality of the environment. Finally, the EU Charter of Fundamental Rights states in its Article 37 that: "A high level of environment protection and the improvement of the quality of the environment must be integrated into the policies of the Union and ensured in accordance with the principle of sustainable development". In sum, the environmental policy of the European Union focus on combating climate change and on protecting the environment.

\section{GMOs and THEIR Impact on Human, Plant and Animal Health}

Known environmental problems include: (i) atmospheric and marine pollution; (ii) global warming and ozone depletion; (iii) the dangers of nuclear and other extra-hazardous substances and; (iv) threatened wildlife species. ${ }^{35}$ Air and water are considered transboundary pollution issues because they can be generated in one state and can have a serious impact in other countries. Therefore can be said that the right to a clean and healthy environment is an international concern.

Philippe Sands ${ }^{36}$ and Alexander Kiss ${ }^{37}$ explain that the planet faces a diverse and growing range of environmental challenges which can only be addressed through international cooperation. These challenges include:

(i) The Greenhouse effect;

(ii) Climate change and;

(iii) Loss of biodiversity.

35 Malcolm Shaw N., INTERNational LaW 613 (UK, Cambridge University Press) (2014).

36 Philippe Sands, Principles of INTERvational LaW 3 (UK, Cambridge University Press) (2003).

37 Alexander Kiss et al., International Environmental LaW 637 (New York, Transnational Publishers, Inc. Ardsley) (2004). 
In addition, Sands mentions that the growth of international environmental issues is reflected in the large body of principles and rules of international environmental law which apply bilateral, regionally and globally, and reflects international interdependence in a globalising world. Thus, Climate change and global warming affect the whole world, this can produce direct or indirect environmental problems which may damage human, animal and plant health as well as the environment. All these can be resolved with the cooperation of the international community.

\section{Global Status of Commercialized Biotech/GM Crops Worldwide}

Genetically Modified Organisms (GMOs) are organisms whose genomes incorporate and express genes from another species. Genetically modified (or transgenic) individuals are created by genetic engineering, using suitable vectors to insert the desired foreign gene into the fertilized egg or early embryo of the host. ${ }^{38}$ Transgenic organisms are the result of biotechnology. Its application in sectors such as in medicine (red biotechnology) and agriculture (green biotechnology) has produced a growing number of GMOs and products derived from them. The environmental safety and risks of GMOs are based on the characteristics of the host organism, the introduced traits, the environment into which the organism is introduced, and the interaction between all of these factors, as well as the intended application of GMOs. ${ }^{39}$

The International Service for the Acquisition of Agri-biotech Applications (ISAAA) notes: "Global hectarage of biotech crops in 2016 increased to 185.1 million hectares compared with 179.7 million hectares in 2015, equivalent to $3 \%$ or 5.4 million hectares." "The ISAAA continues: "A total of 26 countries, 19 developing and 7 industrial countries, planted biotech crops in 2016". The top ten countries, each of which grew over 1 million hectares (39\% of global total, similar to 2015), Brazil with 49.1 million hectares (27\%), Argentina with 23.8 million hectares (13\%), Canada with 11.6 million hectares $(6 \%)$, India with 10.8 million hectares $(6 \%)$, Paraguay with $3.6 \%$ million hectares $(2 \%)$, Pakistan with $2.9 \%$ million hectares $(2 \%)$, China with 2.8 million hectares $(2 \%)$, South Africa with 2.7 million hectares $(1 \%)$, and Uruguay with 1.3 million hectares $(1 \%){ }^{41}$

For this article, it is important to mention that Biotech DroughtGard ${ }^{\text {TM }}$ tolerant maize was first planted in the US in 2013. The cultivation of this GM Maize increased from 50,000 hectares in 2013 to 275,000 hectares in 2014

\footnotetext{
38 A Dictionary of Science 350 (Oxford University Press) (2010).

39 OECD, Safety Assessment of Transgenic Organisms, France, OECD Consensus documents, Volume 1, (2006).

40 ISAAA, 2016. Global Status of Commercialized Biotech/GM Crops: 2016. ISAAA Brief No. 52. ISAAA: Ithaca, NY, p. 3.

41 ISAAA, supra note 40 , at 4 .
} 
and to 810,000 hectares in $2015 .^{42}$ This reflects the farmer acceptance of this biotech maize crop and the need to use the GM Maize in the arid zones of the USA. This kind of GM-Maize could be introduced in Mexico but only in the arid zones of the country. However, if this were the case, it would be necessary to implement biosafety measures and monitoring before its release takes place, in order to avoid another introgression in Mexico as occurred in Oaxaca in 2001. This introgression will be explained in the third section of this article.

According to some authors Mexico has between 41, 59 and 65 varieties of maize, ${ }^{43}$ therefore Mexico does not need to cultivate GM Maize or transgenic maize containing a gene from the bacteria Bacillus thuringiensis (BT Maize). José Antonio Serratos Hernández ${ }^{44}$ details 65 varieties of maize in Mexico ${ }^{45}$ which demonstrates the genetic diversity as well as the need to protect these varieties from contamination.

In order to protect the genetic diversity of maize, it is necessary to protect more than two million small scale of marginalized farmers in the country, because they are the guardians of the native germplasm of maize: they retain, maintain, and even modify the genetic diversity present in their territories through exchange, gene flow, and the testing of new seeds. ${ }^{46}$

\section{Benefits and Risks of the Release of GMOs into the Environment and its Effects on Human, Animal and Plant Health}

There are exists benefits and risks of the release of GMOs into the environment. This was and is still being discussed at national and international levels, but the perception of benefits and risks differs from country to coun-

42 Clive, James, Global Status of Commercialized Biotech/GM Crops: 2015. ISAAA Brief, 51. ISAAA: Ithaca, NY, 2015, 5.

43 T.A. Kato ET AL, ORIGEN $\Upsilon$ DIVERSIFICACIÓN DEL Maíz: UNA REVISIÓN ANÁLITICA, México, UNAM, CONABIO, 18 (2009).

44 José Antonio Serratos Hernández, El origeN $r$ La Diversidad EL Maíz EN EL CONTINENTE AMERICANO, México, Greenpeace, p. 16, (2009).

45 Ibid, the 65 varieties of maize in the country are: Ancho, Apachito, Arrocillo Amarillo, Arrocillo, Azúl, Blandito, Blando Sonora, Bofo, Bolita, Cacahuacintle, Carmen, Celaya, Chalqueño, Chapalote, Clavillo, Comiteco, Conejo, Cónico, Cónico Norteño, Coscomatepec, Cristalino Chihuahua, Complejo Serrano Jalisco, Cubano Amarillo, Dulce de Jalisco, Dulcillo Noroeste, Dzit Bcal, Elotes cónicos, Elotes Occidentales, Elotero de Sinaloa, Fasciado, Gordo, Harinoso de ocho, Jala, Lady Finger, Maíz Dulce, Maizón, Motozinteco, Mushito, Nal Tel, Nal-Tel de Altura, Olotillo, Olotón, Onaveño, Palomero de Chihuahua, Palomero Toluqueño, Pepitilla, Ratón, Reventador, San Juan, Serrano de Jalisco, Tablilla, Tablilla de Ocho, Tabloncillo, Tabloncillo Perla, Tehua, Tepecintle, Tunicata, Tuxpeño Norteño, Tuxpeño, Vandeño, Xmejenal, Zamorano Amarillo, Zapalote Chico, Zapalote Grande.

46 José Antonio Serratos Hernández, supra note 44, p. 12. 
Esta revista forma parte del acervo de la Biblioteca Jurídica Virtual del Instituto de Investigaciones Jurídicas de la UNAM http://www.juridicas.unam.mx/ https://biblio.juridicas.unam.mx/bjv https://revistas.juridicas.unam.mx/ http://dx.doi.org/10.22201/iij.24485306e.2019.1.13129

try. ${ }^{47}$ On the one hand, advocates of biotechnology argues that Biotech crops contribute to food security, sustainable development and mitigating climate change. The ISAAA explains that benefits of planting Biotech Crops include": Increase productivity that contributes to global food, feed and fiber security; Self-sufficiency on a nation's arable land; Conserving biodiversity, precluding deforestation and protecting biodiversity sanctuaries; Mitigating challenges associated with climate change; and Improving economic, health and social benefits. ${ }^{\$ 4}$

Table 1. Global Area of Biotech Grops in 2015 and 2016: by Country (Million Hectares)**

\begin{tabular}{|c|c|c|c|c|}
\hline & Country & Area 2015 & Area 2016 & Biotech Crops \\
\hline $1 *$ & USA* & 70.9 & 72.9 & $\begin{array}{l}\text { Maize, soybean, cotton, canola, sugar } \\
\text { beet, alfalfa, papaya, squash, potato }\end{array}$ \\
\hline $2 *$ & Brazil* & 44.2 & 49.1 & soybean, maize, cotton \\
\hline $3 *$ & Argentina* & 24.5 & 23.8 & soybean, maize, cotton \\
\hline $4^{*}$ & India* & 11.6 & 10.8 & Cotton \\
\hline $5 *$ & Canada* & 11.0 & 11.6 & Canola, maize, soybean, sugar beet \\
\hline $6^{*}$ & China* & 3.7 & 2.8 & Cotton, papaya, poplar \\
\hline $7 *$ & Paraguay* & 3.6 & 3.6 & Soybean, maize, cotton \\
\hline $8^{*}$ & Pakistan* & 2.9 & 2.9 & Cotton \\
\hline 9 & South Africa* & 2.3 & 2.7 & Maize, soybean, cotton \\
\hline $10^{*}$ & Uruguay* & 1.4 & 1.3 & soybean, maize \\
\hline $11^{*}$ & Bolivia* & 1.1 & 1.2 & Soybean \\
\hline $12^{*}$ & Philippines* & 0.7 & 0.8 & Maize \\
\hline $13 *$ & Australia* & 0.7 & 0.9 & Cotton, canola \\
\hline $14^{*}$ & Burkina Faso* & 0.5 & ----- & Cotton \\
\hline 15 & Myanmar* & 0.3 & 0.3 & Cotton \\
\hline 16 & Mexico* & 0.1 & 0.1 & Cotton, soybean \\
\hline 17 & Spain* & 0.1 & 0.1 & Maize \\
\hline 18 & Colombia* & 0.1 & 0.1 & Cotton, maize \\
\hline 19 & Sudan* & 0.1 & 0.1 & Cotton \\
\hline 20 & Honduras & $<0.1$ & $<0.1$ & Maize \\
\hline
\end{tabular}

47 Alicia Gutiérrez González, The Protection of Maize UNder the MexicaN Biosafet1 LAW: ENVIRONMENT AND TRADE 18 (Germany, Universitätsverlag Göttingen) (2010).

48 ISAAA 2016, supra note 40, at 1. 
Esta revista forma parte del acervo de la Biblioteca Jurídica Virtual del Instituto de Investigaciones Jurídicas de la UNAM http://www.juridicas.unam.mx/ https://biblio.juridicas.unam.mx/bjv https://revistas.juridicas.unam.mx/ http://dx.doi.org/10.22201/iij.24485306e.2019.1.13129

THE RIGHT TO A CLEAN AND HEALTHY ENVIRONMENT:...

\begin{tabular}{|c|c|c|c|c|}
\hline 21 & Chile & $<0.1$ & $<0.1$ & Maize, soybean, canola \\
\hline 22 & Portugal & $<0.1$ & $<0.1$ & Maize \\
\hline 23 & Vietnam & $<0.1$ & $<0.1$ & Maize \\
\hline 24 & Czech Republic & $<0.1$ & $<0.1$ & Maize \\
\hline 25 & Slovakia & $<0.1$ & $<0.1$ & Maize \\
\hline 26 & Costa Rica & $<0.1$ & $<0.1$ & Cotton Soybean \\
\hline 27 & Bangladesh & $<0.1$ & $<0.1$ & Brinjal/Eggplant \\
\hline 28 & Romania & $<0.1$ & ---- & \\
\hline & Total & 179.7 & 185.1 & \\
\hline
\end{tabular}

Source: ISAAA, 2015 and $2016^{49}$

* Biotech mega-countries growing 50,000 hectares or more

** Rounded-off to the nearest hundred thousand or more

On the other hand, the potential of risks associated with GMOs include introduction of allergenic or otherwise harmful proteins into food, transfer of transgenic properties to viruses, bacteria or other plants, as well as potential detrimental effects on non-target species and the environment. ${ }^{50}$

To understand the problem in Mexico with regards to maize, it is important to consider that maize is a totally $(100 \%)$ open-pollinated (cross-fertilising) crop species, thus a coexistence between GM Maize and native landraces of maize cannot exist. The contamination in Oaxaca in 2001 is evidence of this. ${ }^{51}$ The Mexican Secretary of Agriculture (SAGARPA) imposed a de facto moratorium on the experimental cultivation of GM Maize in 1998, because there was an uncertainty about potential consequences for maize diversity. However, the de facto moratorium did not prevent the planting of transgenic maize, and introgression took place. The 2004 Report of the Commission for Environmental Cooperation (CEG) analysed: (i) gene flow and transgenic maize, (ii) the impact of Living Modified Organisms (LMOs) on biodiversity and on health, (iii) socio cultural impacts of LMOs in Mexico. ${ }^{52}$ The group of experts from the CEC concluded that one explanation for the appearance of GM Maize in Mexico was the fact that farmers may have planted imported maize from the United States for the use in Tortillas, unaware that the grain was from GM crops. The CEC recommended the restriction of maize imports and their monitoring, preservation in-situ and ex-situ of maize, as well as its conservation, due to

\footnotetext{
49 ISAAA 2016, supra note 40, at 3.

50 Victor M. Villalobos A., Oportunidades r amenazas: LOS tRANSGENiCos 75 (Mundi Prensa, México) (2008).

51 Alicia Gutierrez GonZalez, supra note 47, at 59.

52 Maíz y Biodiversidad, Efectos del Maíz Transgénico en México, Informe de Secretariado de la Comisión para la Cooperación Ambiental CGA, (2004), wrewecec.org/files/PDF/Maize-and-Biodiversity_es.pdf.
} 
Esta revista forma parte del acervo de la Biblioteca Jurídica Virtual del Instituto de Investigaciones Jurídicas de la UNAM http://www.juridicas.unam.mx/ https://biblio.juridicas.unam.mx/bjv https://revistas.juridicas.unam.mx/

http://dx.doi.org/10.22201/iij.24485306e.2019.1.13129

the fact that Mexico is a Centre of Origin and Genetic Diversity of Maize. The appearance of contamination demonstrated the complexity of the management of biosafety measures in Mexico, as well as the lack of control at border customs when GM maize is imported from the USA without label or identification. $^{53}$

The release of GM Maize into the environment in Mexico should only be permitted in arid zones and if biosafety measures are implemented. Otherwise, the effects on biological diversity and changes to agricultural and industrial practices, including an increase in environment pollution, would be severe and irreversible. It is expected that the release of GM maize worldwide will increase, and therefore the loss of biodiversity will take place, i.e., native species could be replaced by exotic species. In order to avoid the loss of biodiversity and the loss of maize varieties, Mexico should prohibit the release of GM maize in its territory, except in its arid zones, where there is not genetic diversity to protect, and only if biosafety measure are in place and can be implemented.

Nevertheless, the major concern about the effects on human, animal, and plant health, and about allergies and toxicity. Glyphosate, is the world's most widely produced herbicide, by volume. It is used extensively in agriculture. This chemical is an ingredient in Monsanto's weed killer product Roundup, and glyphosate has become more popular with the increasing market share of crops that are genetically engineered to be tolerant to the herbicide. ${ }^{54}$ World Health Organization (WHO) cancer authorities and the International Agency for Research on Cancer (IARC) recently determined that glyphosate is "probably carcinogenic to humans" (Group 2A). Glyphosate can cause the following conditions in humans: obesity, cardiovascular disease, colitis, Alzheimer's disease, Parkinson's disease, autism and depression among others. ${ }^{55}$

\section{The legal Framework for the Release of Genetically Modified Maize into the Environment in Mexico and in the European Union.}

\section{In Mexico}

Mexico is considered a megadiverse country, it belongs to a selected group of nations that possess the greatest number and diversity of animals and plants,

\footnotetext{
53 Alicia Gutierrez Gonzalez supra note 47, at 61-63.

54 Cressey Daniel, Widely used herbicide linked to cancer, Nature, International Weekly Journal of Science, USA, 24 March 2015.

55 Samsel Anthony and Seneff Stephanie, Glyphosate's Suppression of Cytochrome P450 Enzymes and Amino Acid Biosynthesis by the Gut Microbiome: Pathways to Modern Diseases. EnTropy 2013, 15, 1416-1463, available at http://wrew.mdpi.com/1099-4300/15/4/1416/html.
} 
or nearly 70 per cent of global species diversity. There are 18 megadiverse countries: Australia; Brazil, China; Colombia; Congo; Ecuador; India; Indonesia; Madagascar; Malaysia; Mexico; Papau New Guinea; Peru; the Philippines, South Africa; the USA; Venezuela; and Zaire.$^{56}$ In addition, Mexico ranks fifth worldwide with 23,424 Vascular plants, 535 Mammals, 1,096 Birds, 804 Reptiles and 361 Amphibians. ${ }^{57}$ Mexico is also a Centre of Origin $^{58}$ and a Centre of Genetic Diversity ${ }^{59}$ (COD) of crops including: chilli pepper; beans; squash; papaya; cotton; tomato; guayaba; cacao; agave; amaranth, and maize.

Mexico faces a major problem with the cultivation of GM maize due to the fact that Mexico has to comply with international environmental commitments and hence has the obligation to protect, conserve and preserve its biodiversity and its maize. Maize is not only the staple food of Mexicans but it has cultural, nutritional, historical, environmental, symbolic, religious, social, and economic significance. ${ }^{60}$ For this reason, Mexico made a declaration against GM maize, which may limit its use for human consumption. The statement establishes that: ${ }^{61}$

- Being Mexico a center of origin and diversification of maize, and: - paying attention to the reproductive biology of maize as an open-pollinated crop; - considering the dynamic character of the traditional farming systems regarding seed exchange and gene flow between local varieties and varieties originated in several geographical regions;

- reaffirming the importance of conservation and sustainable use of that resource; and - understanding the strategic nature of the crop as a food for the Mexican people; manifests that has decided not to allow the release to the environment of genetically modified maize that has been modified in such way as to be no longer suitable as food. That is, Mexico prohibits both experimentation and release to the environment of maize that has been modified to obtain pharmaceutical products, vaccines, industrial oils, plastics, or any modification that limits or affects its properties as food.

We invite all countries that are Parties, as well as all countries that are not Parties to the Cartagena Protocol to think about the use of edible crops, es-

56 For more information see CONABIO, http://werwe.biodiversidad.gob.mx/v_ingles/country/ whatismegcountry.html.

57 Ibid.

58 A centre of origin is the area where a particular organism was first domesticated and brought into use by humans. Centres of origin may still retain a very high diversity of the genetic resources base and wild relatives from which the organism concerned was domesticated.

59 A centre of genetic diversity is an area where there is a high diversity present amongst a particular group of related species - either within a family, genus, or sub-species, varieties, cultivars, strains, or other sub-categories within a species.

60 Alicia Gutiérrez González, supra note 47, at 42.

61 For more information see Biosafety Clearing-House, Convention on Biological Diversity in internet $h t t p s: / / b c h . c b d . i n t / d a t a b a s e /$ record.shtml?documentid $=8601$. 
Esta revista forma parte del acervo de la Biblioteca Jurídica Virtual del Instituto de Investigaciones Jurídicas de la UNAM http://www.juridicas.unam.mx/ https://biblio.juridicas.unam.mx/bjv https://revistas.juridicas.unam.mx/ http://dx.doi.org/10.22201/iij.24485306e.2019.1.13129

pecially in centers of origin, as factories for products that limit its properties as food.

Following this, it is crucial for Mexico to prohibit both experimentation and release to the environment of GM maize that has been modified to obtain pharmaceutical products, vaccines, industrial oils, plastics, or any modification that limits or affects its properties as food because maize is, as mentioned before, the staple food in Mexico. In 2005 Mexico enacted a biosafety $\operatorname{law}^{62}$ and then passed a regulation ${ }^{63}$ of this law in 2008. Together, these are considered the most important regulatory developments on biosafety and biotechnology in Mexico.

Table number 2 shows the annual permits for the release of GM maize into the environment in Mexico. The permits for pilot and experimental programs ran from 14 June 2005 to December 2015.

Table 2. Annual Maize Permits

\begin{tabular}{|c|c|}
\hline Year & $\begin{array}{c}\text { Permits for the release } \\
\text { of GM-Maize into } \\
\text { the environment }\end{array}$ \\
\hline 2005 & 7 \\
\hline $2006-2008$ & 0 \\
\hline 2009 & 33 \\
\hline 2010 & 68 \\
\hline 2011 & 61 \\
\hline 2012 & 33 \\
\hline $2013-2015$ & 0 \\
\hline
\end{tabular}

SOURCE: CIBIOGEM ${ }^{64}$

It is important to note that under Mexican Biosafety Law 202 permits have been granted for the release of GM maize into the environment. ${ }^{65}$ This reflects a lack of protection of maize, even as a COD. Nevertheless, Table 2 shows that between 2013 and 2015, permits for the release of GM maize into the environment were not granted. This happened because of the pres-

62 Ley de Bioseguridad de Organismos Genéticamente Modificados [LBOGM][Biosecurity law of genetically modified organism], as amended, Diario Oficial de la Federación [D. O.], 18 de marzo de 2005 (Mex.).

63 Reglamento de la Ley de Bioseguridad de Organismos Genéticamente Modificados [RLBOGM][Regulation of the biosafety law of genetically modified organisms], as amended, Diario Oficial de la Federación[D.O.], 19 de marzo de 2008 (Mex.)

64 CIBIOGEM, http://wrww.conacyt.mx/cibiogem/index.php/permisos-por-cultivo-annual.

65 Ibid, http://wrewe.conacyt.mx/cibiogem/index.php/estadisticas-comparativo-pruebas-de-campo-ypermisos. 
sure on behalf of environmental organizations including the organization "Sin Maíz no hay País" and "Greenpeace", as well as researchers, farmers, citizens, and so forth. Contamination of maize took place in Oaxaca in 2001, and these organizations and researchers do not want to have another introgression. They continue to demand the implementation of a de facto moratorium and want the government to prohibit the cultivation of GM maize in Mexico, due to the negative effects that this type of maize provoke on human, animal and plant health as well as into the environment. ${ }^{66}$

Researchers and authors recommended the re-installation and maintenance of the release of GM maize in Mexican territory because:

(i) The centres of origin and diversity are not precisely identified,

(ii) Infrastructure for the control of transgenic maize is still not in place,

(iii) The degree of transgenic contamination of maize varieties throughout the country has yet not been determined,

(iv) Programs for the protection, conservation and improvement has been not developed.

Recently, Elena Álvarez-Buylla published in Gaceta UNAM that Glyphosate was present in the maize food chain in Mexico, at rates of almost $30 \% .{ }^{67}$ She and other authors published in Agroecology and Sustainable Food System ${ }^{68}$ that they have found glyphosate and AMPA residues in $27.7 \%$ of samples assayed for herbicide presence. They also stated:

In Mexico there are no set limits for glyphosate residues in processed food, and the concentration of such herbicide is not assayed by official entities. This study suggests that given yhe high level of maize consumption in Mexico, the latter issue should be further considered.

Our results imply that transgenic maize varieties, produced abroad under industrial agricultura are finding their way into the food manufacturing industrial networks inMexico. Another possibility is that domestic seed stocks, that are supposed to be free of transgenic materials, contain at least some GM maize, which suggests that currently applied biosafety guideines should be profoundly revised at the COD of Maize: Mexico. ${ }^{69}$

\footnotetext{
66 National campaign Sin maíz no hay país, in defense of food sovereignty and the reactivation of the Mexican countryside. For more information see: http://sinmaiznohaypais.org/ archivos/250.

67 Alvarez-Buylla, Elena, GaceTA UNAM, "Invasión de Maíz transgénico", UNAM, 4, 904, 18 de septiembre de 2017, p. 8.

68 E. González-Ortega, A. et al., , "Pervasive presence of transgenes and glyphosate in maize-derived food in Mexico", Agroecology and Sustainable Food Systems, vol. 41, Iss. 9-10, 2017, http://dx.doi.org/10.1080/21683565.2017.1372841.

69 Ibid.
} 
As has been demonstrated, Mexico did not learn from the introgression in Oaxaca in 2001. Sixteen years later (2017), Mexico has not applied biosafety measures properly, as there is a presence of GM maize into the maize chain food in Mexico. This indicates that the regulations in place do not work as they should.

\section{The European Union}

The European Union has established a strict regime regarding the cultivation and consumption of genetically modified organisms. Directive 2001/18/ EC of the European Parliament and of the Council and Regulation 1829/2003 of the European Parliament and of the Council establish a comprehensive legal framework for the authorization of GMOs, which is fully applicable to GMOs to be used for cultivation purposes throughout the Union as seeds or other plant-propagating material (GMOs for cultivation). ${ }^{70}$ Under that legal framework, GMOs for cultivation are to undergo an individual risk assessment before being authorized to be placed on the Union market in accordance with Annex II to Directive 2001/18/EG taking into account the direct, indirect, immediate and delayed effects, as well as the cumulative long-term effects, on human health and the environment. The aim of this authorization procedure is to ensure a high level of protection of human life and health, animal health and welfare, the environment and consumer interests. In addition, the precautionary principle should always be taken into account. ${ }^{71}$

The Directive (EU) 2015/412 states:

Member States have the possibility to restrict or prohibit the cultivation in all or part of their territory of a GMO or of a group of GMOs defined by crop or trait, once authorized, on the basis on town and country planning, land use, socioeconomic impacts, coexistence and public policy. ${ }^{72}$ But there is a restriction for Member States. Once a GMO is authorized for cultivation purposes in accordance with the Union legal framework on GMOs and complies, as regards to the variety that is to be placed on the market, with the requirements of Union law on the marketing of seed and plant propagating material, Member States are not authorized to prohibit, restrict, or impede its free circulation within their territory, except under the conditions defined by Union laws. ${ }^{73}$

70 Directive (EU) 2015/412 of the European Parliament and of the Council of 11 March 2015 amending Directive 2001/18/EC as regards the posibility for the Member States to restricto or prohibit the cultivation of genetically modified organisms (GMOs) in their territory. Official Journal of the European Union, in the whereas clauses p. 1, (1) L68.

71 Ibid, supra note 63, in the whereas clauses 1 (2).

72 Ibid, in the whereas clauses 3 (13).

73 Directive (EU) 2015/412, in the whereas clauses, supra note 69, 2 (5). 
It is important to mention that the cultivation of GMOs is an issue addressed at the level of Member States, but issues related to importing and placing GMOs on the market should remain regulated at the European Union level, so as to preserve the internal market. ${ }^{74}$

In order to guarantee a high level of consumer protection, Member States and operators should also take effective labelling and information measures pursuant to Regulation (EG) No 1829/2003 ${ }^{75}$ and Regulation (EG) No 1830/2003 of the European Parliament and of the Council to guarantee transparency with regard to the presence of GMOs in products. ${ }^{76}$ Article 26b, 3 of the Directive (EU) 2015/412 states:

A Member State may adopt measures restricting or prohibiting the cultivation in all or part of its territory of a GMO, or a group of GMOs defined by crop or trait, once authorised in accordance with Part $\mathrm{C}$ of the Directive (EU) 2015/412 or with the regulation (EG) No 1829/2003, provided that such measures are in conformity with Union law, reasoned, proportional and nondiscriminatory and, in addition, are based on compelling grounds such as those related to:
a) Environmental policy objectives;
b) Town and country planning;
c) Land use;
d) Socio-economics impacts;
e) Avoidance of GMO presence in other products without prejudice to Article
f) $26^{a}$ of the Directive (EU) 2015/412;
g) Agricultural policy objectives;
h) Public policy.

74 In the past, in order to restrict or prohibit the cultivation of GMOs, some Member States had recourse to the safeguard clauses and emergency measures pursuant to Article 23 of Directive 2001/18/EG and Article 34 of Regulation (EG) No. 1829/2003 as a result of, depending onthe cases, new or aditional information made available since the date of the consent and affecting the environmental risk assessment, or of the reassessment of existing information. Other Member States have made use of the notification procedure set out in Article 114 (5) and (6) TFEU which requires putting forward new scientific evidence relating to the protection of the environment or the working environment. In addition, the decision-making process has proved to be particularly difficult as regards the cultivation of GMOs in teh light of the expression of national concerns which do not only relate to issues associated with the safety of GMOs for health or the environment.

75 Regulation (EG) No 1829/2003 of the European Parliament and of the Council of 22 September 2003 on genetically modified food and feed, L 268.

76 Regulation (EG) No 1830/2003 of the European Parliament and of the Council of 22 September 2003 concerning the traceability and labelling of genetically modified organisms and the traceability of food and feed products produced from genetically modified organisms and amending Directive 2001/18/EG (O) L268, 18.10.2003, 24. 
Those grounds may be invoked individually or in combination, with the exception of the ground set out in point $(\mathrm{g})$ which cannot be used individually, depending on the particular circumstances of the Member States, region or area in which those measures will apply, but shall, in no case, conflict with the environmental risk assessment carried out pursuant to the Directive (EU) 2015/412 or to Regulation (EG) No 1829/2003.

In the European Union only four countries continued to plant biotech crops in 2016 led by Spain, Portugal, Slovakia and Czech Republic. They experienced a combined increase of 17 per cent in 2016 at 136,363 hectares, compared to 116,870 in 2015. Romania decided not to plant GMOs in 2016 due to onerous government requirement. ${ }^{77}$ As mentioned, Mexico has not yet reached its objective to protect maize because it lacks the infrastructure for the control of GM maize. In addition, programs for the protection and conservation of maize have been not developed. In the European Union, Member States of the EU may adopt measures restricting or prohibiting the cultivation in all or part of its territory of a GMOs, as well as ensuring they have been labelled to guarantee a high level of consumer protection.

\section{Concluding Remarks}

The right to a clean and healthy environment has been adopted on a regional level through agreements including the Protocol of San Salvador in America and the Aarhus Convention in Europe. The national level, the constitutions of some states have include and adopt this right, in order to protect the environment and human, animal and plant health.

As we have seen, the protection of the environment is a challenge not only for Mexico and the European Union, but for the entire international community. Therefore, international cooperation on this issue is needed. In addition, the implementation of the two approaches adaptation and mitigation, adopted in the Kyoto Protocol and the Paris Agreement, must be implemented at local, regional and international levels in order to guarantee the right to a clean and healthy environment.

It is expected that the release of GMOs and GM maize into the environment will increase according to the ISAAA and this may produce negative effects on the environment because of the loss of biodiversity and the replacement of native species. In addition, WHO cancer authorities and the IARC, determined that glyphosate is "probably carcinogenic to humans" glyphosate is an ingredient present into GM maize. For this reason, the consumption of Biotech-crops could damage not only human health but plant and animal health as well. Although it is practically impossible to stop the release of GM

77 ISAAA 2016, supra note 40, 7. 
maize and GMOs into the environment worldwide, and its effects on human, animal and plant health, it should be possible to restrict or impede, as in the European Union, the release of GM maize in Mexico, in order to conserve and protect maize, the staple food of Mexicans. 